\title{
UNLIVED LIFE: THE DEATH AND FUNERAL OF A CHILD IN SLAVIC TRADITIONAL CULTURE
}

\author{
Irina Sedakova \\ Sc.D., Head of the Department for Typology and Comparative Linguistics \\ Institute for Slavic Studies, Russian Academy of Sciences, Russia \\ irina.a.sedakova@gmail.com
}

\begin{abstract}
This ethnolinguistic study based on the analysis of the archival and field data from various Slavic traditions gives an account of the reasons, meaning, and folk comprehension of untimely death - that of a child. Such a tragic event is seen as a result of intricate reasons: God's will, the fate, the verdict of the Fates, parents' ban on the rules, and lack of veneration of the saints, black magic, the evil eye, curse, etc. The amalgamation of Christian views and the pre-Christian perception of early death brings about a combination of notions that seem to be impossible, even more since fatalism comes along with the simultaneous assurance that an early death can be averted with the help of rites and magic acts performed on a newborn baby. Magic programming of a baby's longevity, which starts with the conception and goes through the delivery and postpartum period, various signs, omens, fortune-telling, and prophetic dreams are scrutinized in the first part of the article. Further on the specifics of the funeral of a baby are analysed, with special attention paid to the magic means to separate the baby from the mother and to prevent the death of other children. The types of commemoration and the obstacles of a baby's fate in the other world are also investigated in terms of reflecting the behaviour of the deceased child's relatives. To conclude, the author depicts the stability of some archaic beliefs which one can observe at a child's funeral, and commemorative practices nowadays.
\end{abstract}

Keywords: childbirth, death, ethnolinguistics, fate, funeral customs, magic, Slavic studies

\section{INTRODUCTION}

The article considers popular ideas and beliefs related to early death (in infancy or in childhood), its causes and ways of prevention. Specific Slavic features of a child's funeral and commemoration, beliefs about their posthumous fate are also analysed. As far as I know, these issues have not been subjected to special investigations. An article by Galina Lozanova is devoted to children's funerals among the Southern Slavs (Lozanova 1989), several publications are devoted to local traditions (see Korolyova 2018); certain chapters on "irregular burials" 
can be found in a series of monographs on life circle rites of the Slavs (Navrátilová 2004; Bizeranova 2013). Some topics related to death and child's funeral are elucidated in ethnolinguistic dictionaries (Tolstoi 1995-2012; Makarijoska 2016). I have drawn upon data of folklore and ethnographic studies, archive materials and my own records, made predominantly among Bulgarians living in Bulgaria and in diasporas, and have used these as my principal material. I do not provide a reference for some widespread and well-known beliefs and ethnographic facts. The situation I am characterizing embraces the end of the nineteenth up to mid-twentieth centuries, though some superstitions are still alive and can be documented in most archaic Slavic regions and even in urban settings.

The main methodology of this study lies within the Moscow (Slavic) Ethnolinguistic School, founded by Nikita Tolstoi in the 1970s, and maintains its popularity with many followers up to the present day. The Slavic Ethnolinguistic School uses a multidisciplinary approach to the linguistic and extra-linguistic facts, adducing data from languages, all folklore genres, beliefs, and rituals.

Before I begin the special analysis of rites and beliefs connected with an early death, I would like to mention, at least briefly, the popular views about a human life term (Russian век) as allotted to a person, i.e., the term of mortal life. A life lived 'normally', as it is thought, ends at a venerable age with a natural death. The life 'unlived', without going through all the life stages (growing into adulthood, being wed, the birth of children and grandchildren, and ageing), taken away by accident - a premature death - is perceived in traditional culture as an anomaly, an aberration, and an unhappy fate of the departed and also of their relatives. Also, the death of a son or a daughter, even if they do not die young, presents a tragic anomaly, a permanent grief, a violation of 'life rules' for the parents who survive their child.

An early departure from life in babyhood, childhood, in adolescence or even at a more mature age, but prior to parental death, is believed to be conditioned by a whole set of reasons. According to beliefs, a child's death is written in his or her fate or even in the fates of their parents that are designated by the Fates or other spirits (Plotnikova \& Sedakova 2012; Sedakova 2012). According to other beliefs, such a premature tragic death is prescribed by God; occasionally the midwife sees it after the baby is born, but with no chance to be changed, since this is His will (Vlaskina 2009: 237). Besides, the Slavs traditionally believed in the effectiveness of the evil eye, spells, curses, and verbal magic. A child may die due to a curse sent during a 'bad time', which came true (Vasilevich 2010: 166). A cause of early death was often thought to be due to the parents' non-compliance (mothers are the more frequent culprits) with recommendations specific to traditional communities (a mother's work during feast days and 
a disregard of patron saints), a neglect of traditional folk restrictions and recommendations that turn unhappy events off, of magic acts against evil spirits, etc.

The amalgamation of Christian views and the pre-Christian perception of early death brings about a combination of contradictory views, i.e., fatalism and the simultaneous assurance that early death can be averted with the help of rites and magic acts that may model a long life for a newborn baby (Sedakova 2012). The modelling of a normal, happy life including longevity is mainly written into the birth ritual scenario. The major intention of the pregnant woman, the mother, is the life and health of her offspring as opposed to death. Magic acts aimed at longevity are at the centre of ritual practice before and after labour. In addition, a great amount of attention is paid to various signs, omens, and fortune-telling, prophetic dreams, life facts, and coincidences that are interpreted predominantly in terms of life and death throughout pregnancy, as well as during and after the childbirth.

\section{PREVENTIVE MEASURES AGAINST EARLY DEATH: DIVINATIONS AND OMENS}

\section{Pregnancy}

The Slavs began to take care of healthy and viable yet-to-be-born children at the wedding and immediately after the wedding. Young couples were forbidden to eat bread brought from burials and commemorational services in the year following their wedding; otherwise their children would not stay on the Earth (would not survive). Each folk tradition specifies unlucky days for conception, so on certain days sexual contacts were forbidden. For example, according to Bulgarian beliefs, a quick death awaited children conceived the night before a Friday, Wednesday, or Saturday (Sedakova 2011: 186).

People feared mentioning and showing off a pregnancy because of the many dangerous things which could be 'done', as was believed, to the mother and the foetus; women would wear wide dresses until it was impossible to hide the belly. This is in drastic contrast to the behaviour of modern mothers-to-be; on the internet, they do declare their pregnant status immediately after it has been confirmed, and wear tight-fitting dresses that show the belly (Sedakova 2016: 171-172).

In traditional views, pregnant women had to follow a number of bans to ensure the safety of their children in the future, and to protect them from accidental deaths due to specific circumstances. Bulgarian women never worked on Fridays to avoid the death of their children by fire; they never sat on the 
place where logs for home ovens were chopped up to avoid the death of their children by an axe, and Serbian women did not take baths in rivers to avoid their children drowning in the future (Sedakova 2011: 186). Byelorussian pregnant women were not allowed to sit down on the well wall nor to bring in home fire from another house, or the child will either hang himself/herself or be drowned (Vasilevich 2010: 48).

A set of ideas and interdictions are known (and occasionally still practiced) to prevent the death of a child due to cord entanglement during birth. To avoid this fate, pregnant women were forbidden to wear beads, to knit, and to step over ropes (Kabakova 2009). It was thought that if a baby born with cord entanglement survived, it would augur an evil event: when the child became an adult, they would either hang themselves or be hanged.

Certain omens were thought to predict an early death of a child, even if they appeared during pregnancy. If black blots were seen on the nails of a pregnant woman or if she wanted to eat fish, it was thought, in the Russian North, that she would give birth to a stillborn child or that her child would die in the mother's womb long before the term of labour was due (Sedakova 1997: 9). Byelorussians believed that if a pregnant woman wanted to eat honey or salted fish, her child would have a short life (Vasilevich 2010: 48). Honey as a commemorational food, the colour black and fish are associated with death; as such the symbolism here is crystal clear.

\section{Labour and postpartum period}

If the childbirth was successful, the mother, the midwife, and occasionally some other people present tried to guess whether the baby would live or not. A child's term of life was related to the phases of the moon at the moment of his or her birth: a young or full moon predicted a long life and a birth after the change of the moon augured an imminent death. The position of the sun was also taken into account: children born after midday, particularly at sunset, were doomed to an early death and were not viable. Days of the week when a birth took place were interpreted differently. It was a widespread belief that early death or serious illness awaited children born on a Friday (Sedakova 2007: 354). The Slavs also thought that the birth, just like the conception, on a Wednesday, Friday, and especially on a Saturday augured an early death and a short life. When a birthday coincided with a big feast like Christmas, Easter, commemorative days, days of funerals of grandparents, and serious losses or damages to a household, or just "an unlucky day", these predicted a short life for a baby (Loginov 1993: 107). Months also had their meanings: according to the beliefs of Eastern Slavs, children born in March would not live long. 
The first sounds of a baby served as a basis for guessing its life expectancy. Byelorussians believed that those who cried out right upon being born would live long, while 'revived' babies (those who had been born silent and had given sounds only after a pause) would be ailing and not viable (Vasilevich 2010: 102).

The appearance of a baby also predicted a great deal about its health and longevity. It was thought that a corpulent, heavy child would not live long because the Earth 'pulled him down', while a 'raw' (i.e. 'unready', 'uncooked') child with a 'dilapidated', 'forked' head and long hair, blunt eye corners, soft ears, and a pointed chin was doomed to an early death or a short life. Feet wet with fat and the skin colour were deemed signs to think about the potential term of a baby's life. White and blue skin, especially on the bridge of the nose, was interpreted as a sign of an imminent, early death.

There are many magic actions in birth rites that were aimed not only at producing longevity but also preventing of evil magic which might cause severe illnesses or death. In Bulgaria, it was forbidden to use black thread for fastening the umbilical cord in order to prevent a child's death (Mikhailova 1986: 212). There are eyewitnesses' accounts that it was forbidden to take out the afterbirth from the yard where a child was born because it was thought that the mother and the newly born child would follow the same path ('feet first') (ibid.: 213). In popular medical ideas the afterbirth was perceived as the child's twin and therefore connected to the child's life. It was believed that if somebody were to dig it out, it might be used for harm and the child could die, while his mother would remain childless forever (Popov 1994: 127).

The choice of name had a magical nature, too, the major intention being longevity (on other aspects of choosing the name see Sedakova 2007: 108-115). The Slavs tried to choose a 'strong' saint's name (George, Michael, Nedelya, Petka, etc.) for a newborn baby, especially if labour was difficult or if the child was particularly desired and impetrated after a long, childless marriage. It was forbidden to name somebody in honour of a saint whose feast had already passed; otherwise the newborn would not live long.

In some regions, it was forbidden to give the same names to children within a family; this foretold an early death to one of the namesakes (Listova 2001: 607,611 ), though it was a widespread practice to give names in honour of living grandmothers and grandfathers among the Balkan Slavs. An exception was made occasionally for the first child born immediately after the death of the person whose name the baby was supposed to take on. Early death was explained by the use of the name of the dead relative. The very name with transparent meaning 'to stay, to survive' often implied opposition to death (e.g. South Slavic names Zhivko, Traiko, Stoian, Stoika; for more details see Tolstoi \& Tolstaia 1998; Krusteva-Blagoeva 1999; Sedakova 2007: 108-128). Names given before 
baptism were kept in secret (Serbs sometimes did that until the wedding), to drive away the evil spirits capable of taking the baby with them.

The first wrapping of a child in diapers was also associated with counteracting death. The idea of a long life could be expressed by the usage of clothes of senior relatives, grandfathers and grandmothers, to make diapers; this transferred the seniors' longevity to the child. For the same reason many Slavs used to put an ancient coin into the water in which a child took a bath (Simonides 1988: 31). Also, white wool was brought to feasts in commemoration of a child's birth. Elderly guests praised the child wishing them health and long life, for example, "Stay healthy, live long like me, until your hair grows white (grey)" (Mikhailova 1999: 365; Popov 1994: 137).

The recommendations for taking care of babies did not contain only positive activity. The set of rules also included actions that warded off evil magic because babies were thought to be the most vulnerable to harm. Particular attention was paid to sleep, in addition to the fact that sleep is required for the normal development of a child (see Agapkina \& Toporkov 2020). In archaic thought, sleep in many respects is tantamount to death, and the cradle is taken as an analogy to coffin (Tsiv'ian 1982). Therefore, people paid attention when a child fell asleep quickly after being placed in the cradle for the first time; if this happened, then an early death was expected. If a child slept with open or semi-open eyes, it was thought that they would not live until their third birthday. There were many bans that existed along with the aforementioned signs. For instance, it was forbidden to demonstrate a sleeping child to those who had not seen them yet; this was done to avert the child's death. The Slavs tried not to bring a cradle into the house before the birth of the first child; they had a universal ban on rocking empty cradles, and one of the explanations was that it was feared to draw death to a child. In a series of items and actions that people associated with death and funeral-commemoration rites, I would like to mention one more warning which is related to the careful treatment of mirrors: the Slavs believed that if a child would see his or her image in the mirror, they would die.

Safety prescriptions also dealt with potential accidents. For instance, mothers were forbidden to touch the house fire for three days after birth to prevent the death of a child caused by fire when the baby begins to crawl. In Bulgarian diaspora in Moldova I put down a memorate about the tragic death of a girl who was eaten by wolves, because her mother had violated the ban to work on the so-called Wolves' Days in November. On these days mothers are not allowed to work so that their children would survive and would not meet wolves (Sedakova 2007: 354). 
Baptism, like birth, is connected with the motifs of life and death through magical acts, omens, and fortune-telling. The time for baptism was chosen specifically: if a child was born during a period of fasting, the christening was postponed to the period of time when the consumption of meat was permitted; otherwise the child would die soon. Those who were invited to bake ritual loaves for birth and baptism celebration were selected carefully: they should not have had recent deaths in the family (Mikhailova 1999: 362). This contributed to the prolongation of the child's bloodline.

Sometimes women died in labour and their children did not survive either; in this case both of them were buried together. The mother passing away had the will to take her child with her to the other world. It is said that the mother of a daughter who had given birth to a child and was departing, asked the daughter what would be done with the child, and got the response: "Don't worry; I'll take it with me". The next day the absolutely healthy baby was found dead; in such a case the child's death was perceived as good: the child was saved from an orphanage or from being a 'superfluous' mouth in an alien family (Bizeranova 2013).

If a mother gave birth to a dead child, it was required to buy calico for 40 shirts or 40 crosses and to dispense them to 40 pregnant women to ensure a better posthumous life for the dead baby (Naumenko 1998: 119).

\section{WHEN A CHILD DIES...}

\section{The perception of a child's death, its reasons and omens}

Views on the death of a child, the ritual complex of his or her burial and commemoration, and the care of the deceased's fate in the other world have much in common with the perception and ritual execution of the natural departure of an aged person (Tolstaia 2012). At the same time there are some specific, 'little' (in literal as well as in figurative sense) moments that make a child's funeral different from the funeral of an adult person.

A. Navrátilová (2004: 244-247) used archaeological data obtained from children's burials, and proved that dead children were perceived as inferior members of society. They did not pass through socializing and thus were not integral members of the society. A child is tightly connected with his or her mother and the family, so the death is written into the family scenario; it changes the status of the parents and influences their fertility in the future. So, a death similar to a birth is not only a physiological act, but a sociological one, too. Mothers and fathers with a dead child, as well as children who had 
a death in the house, were not permitted to take part in many rituals and were restricted from performing some calendar and life cycle customs.

In popular Christian narrations there are texts that explain the reasons for children's death. These interpretations are in line with the explanations of many other phenomena that are presently not still understood. I can adduce a legend told by a Bulgarian elder from the Rouptsi village in 1948 to a girl named Boyana Marinova, who was thirteen or fourteen years old at that time.

Once the Lord, Saint Rangel (Archangel) Michael and the Blessed Mother of God met to discuss and to settle the question in what sequence people should depart to the other world. The Lord said that people should depart in the order of their coming to the Earth, but Saint Rangel interfered and said to the Lord and pleaded him not to interfere since that was not his business. But the Mother of God said that only her words are true and valid, and that there was a need for everybody in the other world, for old people who would take care of the children, and for young people who would work and feed the old and the children. And it became as the Mother of God had said, the old as well as the young, and the children would die. (Bizeranova 2013: 121)

According to the information obtained even as early as the nineteenth and twentieth centuries, under the conditions of indigence and a lack of medical aid, children's mortality was high and a child's death was not an exclusive event. Verbal reactions such as "God has given it and God has taken it away", and "One mouth less", "Thank God, who relieved me of one eater", and "God will not take the soul and it will not leave the body by itself" are known. It was deemed that the parents of a child who died ought not to anger God, otherwise God would not give them any other children. The Slavs knew that their children had been given to God (Bizeranova 2013: 280). The Czechs explained the ban on regretting the death of a child with there being a danger that the child would face an expulsion from Heaven (Navrátilová 2004: 121).

However, even in the poorest families with many children, the departure of a baby was connected with oppressive sorrows that were experienced by mothers with a particular keen. A full integrated analysis of the material in totality makes the ambivalence of the approach evident: on the one hand resignation, the acceptance of death as God's will and the ritual ignoring of death; on the other hand protest, the unacceptance of death reflected with particular intensity in emotional keens for a dead child are observed. A specific situation can be observed in families where children had not stayed alive and several babies had already died. To avoid the death of newborn babies, plenty of ritual actions 
were performed at the death of one of the children in the family as well as at the birth of the next child (Sedakova 1997; Tolstaia 2002).

If a son or a daughter died in infancy, the idea of the whole family's future acquired a particular importance. The departure of a child did not involve the death of other children, and parents were not left alone and childless. Due to those views rigorous regulations were related to the mother in particular as well as to the other participants of the funeral and commemorative actions. Another view of funeral and commemorative rites was focused specifically on the deceased child and their posthumous fate. This also prescribed demanding prescriptions in performing rites.

The causes of an early death could have been lack of hygiene, illnesses, epidemic diseases, or accidents that happened due to lapses of the surrounding people. Even the most natural events were perceived in the context of popular beliefs described above: the evil eye, a curse, the influence of the Fates, a punishment for non-compliance with bans on work on certain days of the week and on feast days, a disregard of saints, the 'errors' of the mother during pregnancy, etc. Such ideas have persisted for a very long time, right up to the present day - people search for a reason to explain their loss. According to field records from Bulgaria, a curse sent to a pregnant woman with the wish for her or for her child to die in labour came true: the following day after the birth of a baby girl, the girl in question died (Bizeranova 2013: 80). In folk songs, the topic of the effectiveness of a curse addressed to an unfaithful girl (or boy) friend is developed (Sedakova 2007: 242). There are many stories of a child's death as a punishment to relatives for the non-compliance with various rules. For instance, people were punished for settling in a new house that had not been blessed yet and soon after that a misfortune came: their child drowned (Popov 2002: 150). Many expeditionary records narrate death as a result of the evil eye, black magic, etc.

Omens of a child's death, as is the case with adults, could occur in the form of prophetic dreams: mothers could have dreams that their hair or one of their breasts was cut off, or that they sustained damage to one of their limbs, that they were standing on the verge of a deep pit, or that they had wandered around the dark woods (Bizeranova 2013: 99-111), or a bird flew off the roof of a house, or a sheep was lost from the herd. One woman had a dream before the death of her grandchild; she saw her late husband who took a piglet from her and carried it away in the same way as one would carry a dead body (Bizeranova 2013: 99). 


\section{Baptized/unbaptized dead babies}

Several parameters affect the perception of a child's death, the ritual execution of their funeral and the regulation of the parents' behaviour. As a rule, the fact of a human's baptism and the giving of a name to him or her was fundamental for Christian society and this fact dictated the instructions for a person's funeral and presaged the posthumous fate. Those "without a cross" (not baptized) and a personal name would go to Hell and would be there as if they "were not born" (Shcherbak 2008: 7). So the striving to baptize a child as soon as possible is understandable; if a baby was born weakened, then the priest would allow the midwife or the mother-in-law to perform the baptism; even the father would be allowed to do this (if the child survived, the complete rite of baptism was performed later).

Much has been written about children who died unbaptized, since the belief that they turn into evil spirits and have a hard post-mortal fate is widely spread in Indo-European mythology. I merely mention the facts that are important in the perspective of an early death and the funeral rites. Unbaptized, and consequently 'nameless' children who died were assigned to be buried in the following places: beneath the house, under a window, in the yard, under a tree in the garden, under a rose bush, in a pound for sheep, in the woods, at a crossroads, usually outside cemeteries, but sometimes also near the fence or in a corner of a cemetery. Such children were buried, predominantly, without a cross. There is plenty of information from the Polesie (an archaic area in Byelorussia and Ukraine) region that unbaptized children were buried under thresholds to make people step over them and this way cross them with legs (BD PA). Occasionally before death (or after it) unbaptized children were given names and sprinkled with holy water; after burial the graves were also sprinkled with holy water (BD PA; Popov 1994; Sedakova O. 2004).

The Slavs' beliefs assert that in the other world, the unbaptized child was blind; they sat on the grass, under a tree. They would not go to Heaven; they would go nowhere. Many Slavic (and, in a wider sense, Indo-European) beliefs are recorded and narrate that unbaptized children turn into daemons, into birds that fly crying out in search of their names (for details see Kabakova 1999: 86-87; Radenkovich 2004; O'Connor 2005), or into horses (Sedakova O. 2004: 255).

\section{Age of the baby and obstacles of death}

The manner in which a child died is particularly important. Children who were accidentally suffocated by sleeping mothers were allocated in a particular group. 
Mothers who did that attempted to pray their sin away; they would spend three nights in church, repenting. In the Smolensk region, people recounted:

One aged woman was stricken for three days and lay as a dead person... then revived. Answering the question "Where have you been?" she responded: "A burial ground was shown to me; and I saw that children who had accidentally suffocated in their sleep had a black flower in their hand, while children who died their own deaths held pink flowers." And it was said to her: "Go and announce that to every mother and tell them not to sleep tightly with their children to avoid such a sin." (Naumenko 1998: 119)

The age of the deceased child determined certain aspects of the ritual execution of the funeral and influenced the ideas of what their post-mortem fate would be like. It was deemed that children who died soon after birth would go to Heaven; moreover, they saved their mothers from Hell (Rks: 306). It was believed that there was an apple tree in Heaven with a multitude of shoots resembling female breasts, and that the departed children would make use of these shoots (Bizeranova 2013: 133). Babies have a particular bond with their mothers; if a baby died, extra measures were taken to prevent his or her visits to the mother for breast milk (the mother hid, did not spend nights at home, etc.). Besides babyhood, in descriptions of funerals and commemorations the following age periods were indicated: younger than 3 years, younger than 7 years, younger than 10 years, younger than 12 years. It is noted that elements of a weddingfuneral are included in the commemoration of the dead who had reached the age of thirteen-fourteen (Lozanova 1989: 20).

Children younger than 7 were deemed innocent, guiltless, and therefore they died easily, with no pain. If a child did experience pain, the cradle was put on the floor beneath the house icon and people said: "Its pain is the result of its labour for its parents' sins".

\section{Rituals and beliefs}

It was not customary to spread the news of a child's death as it was done in the case of an adult person's death; information of the tragic event was available only to family members. No funeral wreath or a cloth as a visual sign of a death in the family was to be hung on the gate. The custom known to many Slavs (when a person living in a village died, members of the community needed to discharge barrels and draft fresh water) was not complied with when a child died (Vakarelski 1990: 77). 
Ukrainians put a child's corpse not on a bench in the room, as it was done with adult corpses, but on a table because the dead child was "like an angel". The child was dressed for its funeral in a special way. Ukrainians covered the dead children's faces with a wrap or a piece of cloth. The funeral shirt was sown with a 'living thread' (without knots), irrespective of gender. In the Poltava region the deceased child was often covered with a krizhmo, i.e., a cloth the godmother presented for the baptismal feast (Shcherbak 2008: 73). More often than not, boys and girls were dressed identically: with no headwear, in white shirts and slippers (Fiadosik 1986: 22, 132; BD PA), but gender differentiation is also known: girls got dresses and boys got long shirts; both girls and boys had wreaths placed on their heads.

Children that had passed away were dressed in completely new, holiday clothes presented by the godmother (Mikhailova 1999: 5, 225, 245), with an obligatorily belt. It is explained that the unbelted child would endure hardship in the other world: if an apple were to be given to a child, they would lose it because they would put the apple under their shirt (Bizeranova 2013: 280; Levkievskaia 2009).

There was a belief that a child who died would still grow. Therefore, the sides of their shirt were not sown or even the shirt was cut to avoid any obstacles to the growth. The idea of posthumous growth was understood demonologically. In the Russian North, people believed that children in the other world might overgrow their fathers if they were not stopped. Such dead corpses could turn into evil spirits and 'walk' and 'frighten' people. To prevent this, a thread as long as the father's (or mother's) height was put into the coffin, so the child would not grow taller than the parent (Listova 2001: 623).

Wood shavings, birch leaves or a pillow stuffed with leaves or thyme were placed into the coffin which was normally unpainted. In the Vologda region, Russia, an egg used to be placed for a little one under the pillow and people said: "Let him play with the egg with joy" (Vlasova 1999: 392).

In Bulgaria, the midwife came without fail to the funeral of a baby. She locked the door latch and put it under the dead child's back while the key was dropped into the well to prevent the death of other children. Sometimes the latch was dropped into the grave in order to expel death and to seal the way for it (Mikhailova 1999: 225).

Children's funerals were modest: the child was carried by the godmother, the midwife or the father (Korepova 2013: 171). The Nekrasov Cossacks who emigrated from Russia to Turkey had a custom according to which the dead child was taken to the cemetery by an orphan girl (orphans were also supposed to dig out the grave (Vlaskina 2016: 91-92). In the Polesie region, a dead child (younger than 7 years old) was taken to the grave by six girls who carried the 
corpse on special blankets (Sedakova O. 2004: 243; Fiadosik 1986: 155). If a child was younger than 10, they were carried by coevals (Korepova 2013: 107).

As an example of the account above, I adduce a short description of an archaic rite of the funeral of a baby who was about one or two months old, from the Gymzovo village in north-western Bulgaria; the funeral took place in the 1960s. The description reflects important moments typical for the perception of a child's death as a significant event in the life of the family. The child (regrettably, the author did not specify whether the child was baptized or not, but supposedly it was 'without a cross') was wrapped in diapers and carried out (feet first) through the window. Then, the corpse was buried in the garden in a place that had not been dug out previously, for nothing had been planted there for a long time. The grave was dug out and the coffin was placed with the deceased's head pointing westward in the grave. Though a cross was not put up, the grave was arranged as it is usually done in the cemetery, and flowers were planted. On commemoration days the grave was avoided. S. Bizeranova, who recorded the rite, quotes the words of a female informant: "Thus people strove to prevent the death of the next child who would be born" (Bizeranova 2013: 218).

\section{To keep fertility in the family}

Having quoted this account, I proceed to a very important part of the topic: customs and rites that were qualified to protect a family that had lost a child from the loss of other children. Whether the firstborn died or there were other children in the family, was deemed as an important circumstance to consider. In any case, a preventive ritual was developed in detail. In the Serbian village Oshlyane, before the deceased child was deposed on the bier, all of the buttons on his or her shirt were unfastened; otherwise their mother would be unable to conceive again. Cases of an inability to conceive explained with the non-compliance with the aforementioned rule have been recorded. To 'correct' this mistake, the grave was exhumed and the buttons were unfastened. The mother soon conceived and gave birth to a healthy baby (Krstich 2003: 155).

When the procession went to the cemetery, somebody had to stay at home to prevent the death of the other children. The door was closed for a minute after people stirred from the house with the same reasoning. All the Slavs banned the participation of the mother and often also the father in the funeral of the firstborn child. Parents were even disallowed to approach the coffin of their child, particularly if the deceased child was the firstborn; the time and the place of the funeral were concealed. A mother would not bury her firstborn; if this ban 
was violated, the mother would bury 'all of the other children'. If a boy died, his grave was circled around three times cum sole to ensure that his mother could give birth to other children. Bulgarians whirled wreaths of geranium and decorated the mother with them, and she danced in the yard "to prevent the evil's joy" after the lifting of the body (Rks: 79).

When a firstborn child died, mourning clothes were not worn for them, though they were worn for subsequent children: Bulgarian men did not wear headgear, girls did not plait their hair, and women did not wear beads and straps for three days. Some parents kept on observing the mourning period until the end of their own lives (Bizeranova 2013: 203, 204, 269, 279).

For a single child in the family a window was cut in the coffin in order not to lock the way to other children. The child's items were destroyed for the same purpose. Southern Slavs' fathers used to burn the cradle behind the mother's back. Diapers were burnt or were given away to the Romany (Popov 1994: 205; 2002: 138). The Bulgarians living in the Sakar region had a custom to destroy the house where the firstborn child died, and to build a new house with the clothes of the deceased put under the foundation (Popov 2002: 138). Southern Slavs practiced a considerable array of magical acts in the case when one of the twins or of the children born in the same month or on the same day, although in another year, died (Plotnikova 2004).

\section{Posthumous acts and commemorations for the children}

Food for children, sweets, eggs, and milk were put on the table at wakes and subsequent commemorations. Fruits were left at the grave and the grave was watered. The custom to dispense food on commemorative days (it was an accepted practice among the South Slavs) presupposed the baking of special loaves, but these were smaller; Byelorussians baked special biscuits called ladki to prevent the deaths of other children in the family (Fiadosik 1986: 170). There are many interesting local and ethnic details regarding the way and the kind of the food served for the children. The Cossacks from the Don Delta would not lay the table, but put the bowls with sweet milk and egg pasta on the floor or on a meadow covered with a cloth. This food was cooked especially for the children of the same age as the deceased child was (Matishov et al. 2012: 179-180). As Albert Baiburin argues, a commemorative meal placed close to the earth was usually meant for those who had not died in a normal way and untimely (Baiburin 1983: 156).

Age-mates of the deceased were gathered at wakes and remnants of the commemorative food were given to a child of the same gender as the deceased one. 
Children performed an important role in funeral and commemorative rites, particularly if they were age-mates of the deceased child. There was a custom among Romanian Old Believers I documented in Tulcha in 2007: the mother would select a child of the same gender and age as her deceased child, and make presents and clothes for him or her for every feast. At Whitsun, the parents of the deceased child gathered children of the same age and treated them to food and sweets. Living children are actually intermediaries between parents and their deceased children. A particular piece of evidence of this might be the following dream: the mother of a deceased child dreamed that he carried plenty of cookies; she asked where the boy got the cookies and he answered that these were the cookies that she had bought and dispensed (Korepova 2013: 182).

Information and field materials on the terms and dates of commemoration are contradictory. For example, according to the data adduced by S. Bizeranova, in north-western Bulgaria a deceased child was not commemorated after the fortieth day (Bizeranova 2013: 280-281). But there is information that in another region of Bulgaria, in Lovech, a mother who had lost her child visited all of the funerals in her village and bewailed her child (Mikhailova 1999: 416). However, the commemoration of a deceased child (not only a baby but also an adult one who died before parents) for the rest of the mourner's life was more widespread.

Bulgarians believe that a deceased child remains with his or her mother until the fortieth day. On that day, the Mother of God tries to separate the child from the mother but the child cries and does not want to follow the Mother of God. She then throws an apple and the child chases it. A well-known restriction bans the mothers whose child has died to eat apples until the Feast of Transfiguration of Our Lord (August 6/19). People believe that the Mother of God dispenses apples only to those children whose mothers follow the recommendation and deprive those children whose mothers do follow the restriction (Belova 2012). We can see some allusions to it in the habit of the Byelorussian mothers who have lost their children: they leave the first three seasonal berries they have gathered on the ground (Vasilevich 2010: 166).

\section{The child in the other world}

The relatives and villagers comment on the posthumous fate of deceased children in detail. A deceased child is deemed to be 'pure from sin' and is perceived as an 'angel', a cherub; though there are differences that depend on the age of the child. For instance, Russians believe that children of two-three years of age become angels by all means, while a child of seven years of age will go 
to Heaven (Naumenko 1998: 116). If a child reaches eight years of age, then their fate is determined "in accordance with their sins" (Shcherbak 2008: 73).

In any case, a deceased person of any age is 'the ancestor': "Be it a baby, or a youngster three years old, it is the servant of God nevertheless" (Korepova 2013: 161). This idea is important for the understanding of the relations between the child and the other dead ('ancestors'), and with those who are still alive. Help for the dead was sought from 'ancestors'; if in the family an adult person died, they were pleaded to take under their protection all the children and youngsters who had died earlier.

It is believed that a child's soul, until the fortieth day, would appear in the form of an insect, a fly, a butterfly or a cricket. Everybody watches where the insects fly to; it is believed that they will go to Heaven. Back in 1983, in a Bulgarian village in Moldova, I was interviewing a woman whose daughter had died two weeks earlier. A butterfly had flown into the room, and the lady immediately reacted: "See, my daughter Mariyka's soul has come to see us."

Tears and lamentations are the frequent motifs in the description of a child's funeral. It is said that until death came, nobody was allowed to cry (the same behaviour was prescribed in the case of an adult's death). However, the reasoning is different: if a dead person is bemoaned, they will descend to a great depth; if they are not bemoaned, they will be translated into Heaven. But people were absolved of crying for the dead because they were angels (Sedakova O. 2004: 170). According to Croatian beliefs, a mother's tears must not get onto the coffin, otherwise the child would sink in the other world or would wear a wet shirt the whole time there (Alaupović-Gjeldum 1999: 156). The ban on tears for a deceased child was explained by the following reasons: the deceased would sink or lie in water. Dreams related to this topic are frequently narrated; for instance, a woman saw her daughter walking along a flooded road; the water had reached her neck and she was close to drowning. An old woman (a grandmother) interpreted the dream and said: "Do not sob; you will sink her in your tears" (Korepova 2013: 181). To stop a mother's longing for her deceased child, charms were read. The grief was 'washed off' in bathhouses where the parents went after the wake, and sand from the grave was scattered beneath the mother's collar; earlocks were sewn up in a small pouch which the mother would then wear on her body. 


\section{CONCLUSION}

The death of a child is an infrequent event now, but its tragic nature surpasses the traditional perception expressed in the saying "God has given, God has taken away". Present-day records bear witness that the beliefs have retained their archaic features in many respects; an early death causes oppressive sorrows for parents and other relatives who are eager to find a logical reason for the tragic event until the end of their lives.

Motifs of an early departure and a life unlived intensify in lamentations over a child. These motifs are transferred by virtue of metaphors, through addressing the child as a premature berry, a cherry, an apple, etc. (Fiadosik 1986: 315; Koval'-Fuchilo 2012: 303, 647).

Deep grave emotions, strict regulations for the performance and behaviour in the family, fear for the future of the deceased person in the other world are typical of all the deaths as perceived in an archaic society. The difference would be in the size of everything that surrounds the death of a child - less information in the village, smaller processions and commemoration rituals.

Infantile motifs have been retained in the present-day funeral and commemorative practices with some innovations. The motif of a 'tiny one' is still dominating: toys, sweets, and other dainties are brought to children's graves, and the names inscribed on monuments (tombs) are pet and diminutive forms (see Russian Lilichka, Tomochka, Bulgarian Dimo, Shushi) (Fig. 1).

Figure 1. A grave of a girl called Lilichka at the Pyatnitskoe cemetery in Moscow. Photograph by Irina Sedakova 2019.

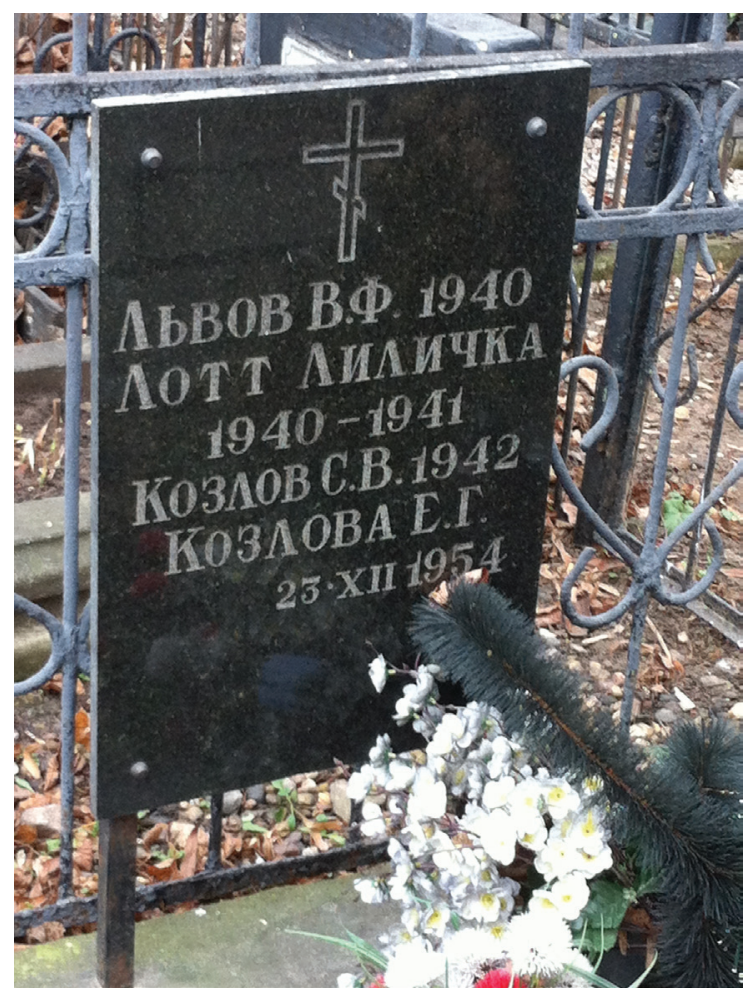




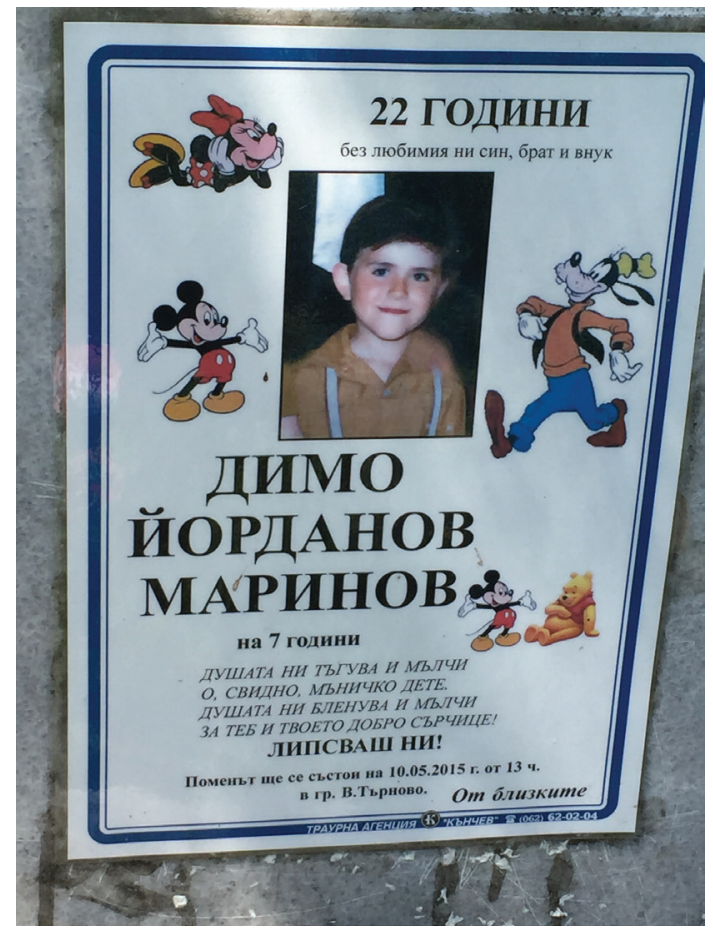

Figure 2. A Bulgarian obituary for a boy of 7 years. Veliko Tarnovo cemetery. Photograph by Irina Sedakova 2017.

Heroes of fairy-tales and decorative elements dominate in obituaries that are widespread in Bulgaria and Northern Macedonia (Fig. 2).

The elements that allude to childhood have particular strong expressions in the commemorations of tragic situations that took many lives, as it happened in the Beslan school act of terrorism, the fire at the "Winter Cherry" mall in Kemerovo, the mass death of children due to bad weather and lack of expertise of the instructors at Lake Syamozero in Karelia, etc.

\section{ARCHIVAL SOURCES}

BD PA = Database "Polessian Archive". Institute for Slavic Studies, Russian Academy of Sciences

Rks = Archival collection of graduate theses written under the guidance of Academician Stefan Romanski. Sofia University "St. Kliment Ohridski” 


\section{REFERENCES}

Agapkina, Tatiana \& Toporkov, Andrei 2020. The Structure and Genesis of One Type of Magic Spell against Children's Insomnia among Slavic Peoples. Folklore: Electronic Journal of Folklore, Vol. 80, pp. 35-46. https://doi.org/10.7592/ FEJF2020.80.agapkina_toporkov.

Alaupović-Gjeldum, Dinka 1999. Običaji zivotnog ciklusa u Imotskoj krajini i zapadnoj Hercegovini, od konca XIX. stoljeća do Drugog svjetskog rata. [Life Cycle Customs in the Region of Imotski and Western Herzegovina from the End of the 19th Century to World War II.] Ethnologica Dalmatica, Vol. 8, pp. 149-168. Available at https://hrcak.srce.hr/file/159857, last accessed on 3 November 2020.

Baiburin, Al'bert 1983. Zhilishche v obriadakh i predstavleniiakh vostochnykh slavian. [Housing in the Rituals and Beliefs of Eastern Slavs.] Leningrad: Nauka. Available at https://eusp.org/sites/default/files/archive/et_dep/Baiburin/baiburin_ zhilishe_v_obriada.pdf, last accessed on 3 November 2020.

Belova, Ol'ga 2012. Iabloko. [Apple.] In: Nikita Tolstoi (ed.) Slavianskie dreunosti: etnolingvisticheskii slovar'. Vol. 5. Moscow: Mezhdunarodnye otnosheniia, pp. 608-611. Available at https://vk.com/doc35528094_464711466?hash=48064 84bb6725d6c54, last accessed on 3 November 2020.

Bizeranova, Sashka 2013. Mezhdu zhivota i smurtta: Pogrebalni i pomenalni obichai pri bulgari i vlasi vuv Vidinsko. [Between Life and Death: Funeral and Memorial Customs among Bulgarians and Vlachs in the Vidin Region.] Vratsa: Aleksprint.

Fiadosik, Anatol' (ed.) 1986. Pakhavanni. Paminki. Galashenni. [Funeral. Commemoration. Lamentation.] Minsk: Navuka i tekhnika.

Kabakova, Galina 1999. Deti nekreshchenye. [Unbaptized Children.] In: Nikita Tolstoi (ed.) Slavianskie dreunosti: etnolingvisticheskii slovar'. Vol. 2. Moscow: Mezhdunarodnye otnosheniia, pp. 86-88. Available at https://vk.com/doc$83903602 \_438147196$ ?hash=23372cb20d6c57b799, last accessed on 3 November 2020.

Kabakova, Galina 2009. Pupovina. [Umbilical Cord.] In: Nikita Tolstoi (ed.) Slavianskie drevnosti: etnolinguisticheskii slovar'. Vol. 4. Moscow: Mezhdunarodnye otnosheniia, pp. 353-354.

Korepova, Klara (ed.) 2013. Fol'klor Sosnovskogo raiona Nizhegorodskoi oblasti. [Folklore of Sosnovskoe District of Nizhniy Novgorod Region.] Nizhniy Novgorod: Rastr-NN.

Korolyova 2018 = Koroleva, Svetlana. "V golbche-to u nas mogil'nik": detskie zakhoroneniia vne obshchego kladbishcha v XX veke (praktiki i narrativy Severnogo Prikam’ia). ["There Are Graves in Our Cellar": Burials of Children Outside Common Cemeteries in the 20th Century (Practices and Narratives of Northern Kama River Basin).] Traditsionnaia kul'tura, Vol. 19, No. 3, pp. 138-149. Available at http://www.trad-culture.ru/sites/default/files/files_pdf/korolyova_0.pdf, last accessed on 3 November 2020.

Koval'-Fuchilo, Irina (ed.) 2012. Golosinnia. [Lamentations.] Kyiv: In-t mistetstvoznavstva, fol'kloristiki ta etnologiï.

Krstich, Dejan 2003. Obichaji i verovanja vezani za smrt u selu Oshljane. [Customs and Beliefs in Connection with Death.] Razvitak, Vol. XLIII, No. 213-214, pp. 147-168. 
Krusteva-Blagoeva 1999 = Krusteva-Blagoeva, Evgeniia. Lichnoto ime v bulgarskata traditsiia. [Personal Name in the Bulgarian Tradition.] Sofia: Akademichno izdatelstvo "Professor Marin Drinov".

Levkievskaia, Elena 2009. Poias. [Belt.] In: Nikita Tolstoi (ed.) Slavianskie drevnosti: etnolingvisticheskii slovar'. Vol. 4. Moscow: Mezhdunarodnye otnosheniia, pp. 230-233.

Listova, Tatiana 2001. Obriady i obychai, sviazannye s rozhdeniem i vospitaniem detei. [Rituals and Customs Associated with the Birth and Upbringing of Children.] In: Irina Vlasova (ed.) Russkii Sever: Etnicheskaia istoriia i narodnaia kul'tura XII-XX veka. Moscow: Nauka, pp. 575-660. Available at http://static.iea.ras.ru/ books/Russian_North_Part_2.pdf, last accessed on 4 November 2020.

Loginov, Konstantin 1993. Semeinye obriady i verovaniia russkikh Zaonezh'ia. [Family Rituals and Beliefs of the Russians in Zaonezhye.] Petrozavodsk: Karel'skii nauchnyi tsentr RAN.

Lozanova, Galina 1989. Osobenosti na obredite pri pogrebenie na detsa u iuzhnite slaviani $v$ kraia na XIX i nachaloto na XX $v$. [Specificities of the Funerary Rites for Children among the Southern Slavs in the Late 19th and Early 20th Century.] Bulgarska etnologiia, No. 1, pp. 17-30. Available at https://www.ceeol.com/search/articledetail?id=226857, last accessed on 4 November 2020 .

Makarijoska, Liljana 2016. Rechnik na makedonskata traditsionalna kultura. [Dictionary of Macedonian Traditional Culture.] Skopje: Institut za makedonski jazik "Krste Misirkov".

Matishov, Gennadii \& Vlaskina, Tatiana \& Venkov, Andrei \& Vlaskina, Nina 2012. Sotsial'no-istoricheskii portret del'ty Dona: kazachii khutor Donskoi. [A SocialHistorical Portrait of the Don Delta: A Cossack Hamlet of Donskoi.] Rostov-onDon: Izdatel'stvo IuNTs RAN.

Mikhailova, Ganka (ed.) 1986. Plovdivski krai: Etnografski i ezikovi prouchvaniia. [Plovdiv Region: Ethnographic and Language Studies.] Sofia: BAN.

Mikhailova, Ganka (ed.) 1999. Loveshki krai: materialna i dukhovna kultura. [Lovech Region: Material and Spiritual Culture.] Sofia: Akademichno izdatelstvo "Professor Marin Drinov".

Naumenko, Georgii 1998. Etnografiia detstva: sbornik fol'klornykh $i$ etnograficheskikh materialov. [Ethnography of Childhood: Collection of Folklore and Ethnographic Materials.] Moscow: Belovod'e.

Navrátilová, Alexandra 2004. Narození a smrt v české lidové kultuře. [Birth and Death in the Czech Folk Culture.] Praha: Vyšehrad.

O'Connor, Anne 2005. The Blessed and the Damned: Sinful Women and Unbaptised Children in Irish Folklore. Bern \& Oxford \& New York: Peter Lang.

Plotnikova, Anna \& Sedakova, Irina 2012. Sudzhenitsy. [The Fates.] In: Nikita Tolstoi (ed.) Slavianskie drevnosti: etnolingvisticheskii slovar'. Vol. 5. Moscow: Mezhdunarodnye otnosheniia, pp. 199-203. Available at https://vk.com/doc35528 094_464711466?hash=4806484bb6725d6c54, last accessed on 3 November 2020.

Plotnikova, Anna 2004. "Odnomesiachniki”, "odnodnevniki”. ["Born in One Month”, "Born on One Day".] In: Nikita Tolstoi (ed.) Slavianskie drevnosti: etnolingvisticheskii slovar'. Vol. 3. Moscow: Mezhdunarodnye otnosheniia, pp. 533-534. Available at https://vk.com/doc-83903602_438147292?hash=1572836179c1dabeeb, last accessed on 3 November 2020. 
Popov, Rachko (ed.) 1994. Rodopi: Traditsionna i sotsialnonormativna kultura. [Rhodopes: Traditional and Social-Normative Culture.] Sofia: BAS.

Popov, Rachko (ed.) 2002. Sakar: Etnografsko, folklorno i ezikovo izsledvane. [Sakar: Ethnographic, Folklore and Linguistic Research.] Sofia: Akademichno izdatelstvo "Professor Marin Drinov".

Radenkovich, Liubinko 2004. Nazvaniia demonov, vedushchie proiskhozhdenie ot detei umershikh do kreshcheniia, u slavian. [The Slavic Names of Demons, Originating from Children Who Died before Baptism.] Balcanica, Vol. XXXIV, pp. 203-221. Available at http://www.balcanica.rs/balcanica/uploaded/balcanica/balcanica\%20 34/13\%20Ljubinko.pdf, last accessed on 4 November 2020.

Sedakova, Irina 1997. "Zhilets" - "nezhilets". Magiia i mifologiia rodin. [Survivor or NonSurvivor: Magic and Mythology in Birthlore.] Zhivaia starina, No. 2, pp. 9-11. Available at https://yadi.sk/i/6mIlTALK3P9vrA, last accessed on 4 November 2020 .

Sedakova, Irina 2007. Balkanskie motivy v iazyke i kul'ture bolgar: Rodinnyi tekst. [Balkan Motifs in Bulgarian Language and Culture: Birthlore.] Moscow: Indrik. Available at https://inslav.ru/publication/sedakova-i-balkanskie-motivy-v-yazykei-kulture-bolgar-rodinnyy-tekst-m-2007, last accessed on 4 November 2020.

Sedakova, Irina 2011. Kategoriia vremeni v slavianskom "tekste rozhdeniia": zachatie i beremennost'. [Category of Time in the Slavic "Text of Birth": Conception and Pregnancy.] In: Svetlana Tolstaia (ed.) Prostranstvo i vremia v iazyke i kul'ture. Moscow: Indrik, pp. 181-197. Available at https://inslav.ru/sites/default/files/ editions/2011_prostranstvo_i_vremja.pdf, last accessed on 4 November 2020.

Sedakova, Irina 2012. The Notion of Fate (Russian cyдьбa) in Slavonic Folk Tradition: An Ethnolinguistic Approach. Cosmos: The Journal of the Traditional Cosmology Society, Vol. 28, pp. 154-169. Available at https://www.academia.edu/10810716/, last accessed on 4 November 2020.

Sedakova, Irina 2016. Clothes as Symbolic and Magic Objects in Slavic Childbirth Customs. Folklore: Electronic Journal of Folklore, Vol. 66, pp. 165-174. https:// doi.org/10.7592/FEJF2016.66.sedakova.

Sedakova, Ol'ga 2004. Poetika obriada: Pogrebal'naia obriadnost'vostochnykh i iuzhnykh slavian. [Poetics of the Ritual: Funeral Ritual Complex of Eastern and Southern Slavs.] Moscow: Indrik. Available at http://www.olgasedakova.com/books/1359, last accessed on 4 November 2020.

Shcherbak, Inna 2008. Obriadovi formi statevoi identifikatsiï ditei. [Ritual Forms of Children's Status Identification.] In: Marina Grimich (ed.) Narodna kul'tura ukraïntsiv: zhittevii tsikl liudini. Tom 1. Diti. Ditinstvo. Ditiacha subkul'tura. Kyiv: Dulibi, pp. 60-81.

Simonides, Dorota 1988. Od kolebki do grobu. Śląski wierzenia, zwyczaje i obrzędy rodzinne $w$ XIX wieku. [From the Cradle to the Grave: Silesian Childbirth Beliefs, Customs and Rituals in the 19th Century.] Opole: Instytut Ślaski w Opolu.

Tolstaia, Svetlana 2002. "Ako se detsa ne drzhe": magicheskie sposoby zashchity novorozhdennykh ot smerti. ["If Babies Die": Magic Preventive Ways of the Death of Newborns.] Kodovi slovenskikh kultura, Vol. 7, pp. 55-87. Available at https:// www.rastko.rs/rastko/delo/11884, last accessed on 4 November 2020. 
Tolstaia, Svetlana 2012. Smert'. [Death.] In: Nikita Tolstoi (ed.) Slavianskie drevnosti: etnolingvisticheskii slovar'. Vol. 5. Moscow: Mezhdunarodnye otnosheniia, pp. 5871. Available at https://vk.com/doc35528094_464711466?hash=4806484bb6725d 6c54, last accessed on 3 November 2020.

Tolstoi, Nikita (ed.) 1995-2012. Slavianskie drevnosti: etnolingvisticheskii slovar'. [Slavic Antiquities: Ethnolinguistic Dictionary.] Vol. 1-5. Moscow: Mezhdunarodnye otnosheniia.

Tolstoi, Nikita \& Tolstaia, Svetlana 1998. Imia v kontekste narodnoi kul'tury. [Name in the Context of Folk Culture.] In: Problemy slavianskogo iazykoznaniia. Tri doklada $k$ XII Mezhdunarodnomu s"ezdu slavistov. Moscow: Institut slavianovedeniia RAN, pp. 88-125. Available at https://inslav.ru/publication/ problemy-slavyanskogo-yazykoznaniya-tri-doklada-k-xii-mezhdunarodnomusezdu-slavistov-m, last accessed on 4 November 2020.

Tsiv'ian, Tatiana 1982. Prostranstvo i vremia v balkanskikh okhranitel'nykh obriadakh, sviazannykh s rozhdeniem rebenka. [Space and Time in the Balkan Preventive Rituals Related to Childbirth.] Makedonski folklore, Vol. 29-30, pp. 117-123.

Vakarelski, Khristo 1990. Bulgarski pogrebalni obichai: Sravnitelno izuchavane. [Bulgarian Funeral Customs: A Comparative Study.] Sofia: Izd-vo na BAN.

Vasilevich, Uladzimir (comp.) 2010. Zhytstsia advechny lad: Belaruskiia narodnyia prykmety i paver'i. [The Traditional Way of Life: Byelorussian Folk Omens and Beliefs.] Vol. 2. Minsk: Belarus'.

Vlaskina, Nina 2009. Kontsept Sud'ba v iazyke i kul'ture donskikh kazakov. [The Concept of Fate in the Language and Culture of the Don Cossacks.] In: Anastasiia Stakheeva \& Nina Vlaskina. Funktsional'nye i etnokul'turnye aspekty izucheniia russkogo iazyka. Rostov-on-Don: Izd-vo IuNTs RAN, pp. 167-373.

Vlaskina, Tatiana 2016. Predstavleniia kazakov-nekrasovtsev o smerti. [Concept of Death among the Nekrasov Cossacks.] Traditsionnaia kul'tura, No. 4 (64), pp. 86-97. Available at http://www.trad-culture.ru/sites/default/files/files_pdf/0 7\%D0\%92\%D0\%BB\%D0\%B0\%D1\%81\%D0\%BA\%D0\%B8\%D0\%BD\%D0\%B0.pdf, last accessed on 4 November 2020.

Vlasova, Marina 1999. Russkie sueveriia. [Russian Superstitions.] Moscow: Azbuka.

Irina Sedakova, PhD, Sc.D., is Head of the Department for Typology and Comparative Linguistics, Institute for Slavic Studies, Russian Academy of Sciences, Russia. Her fields of interest are Slavic and Balkan studies, ethnolinguistics, sociolinguistics, folklore, childbirth and calendric customs.

irina.a.sedakova@gmail.com 